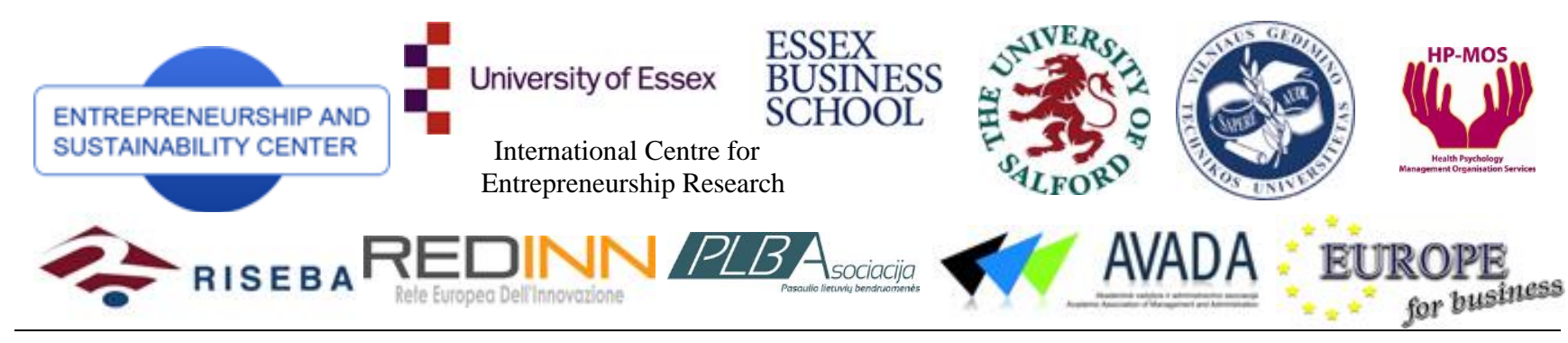

ENTREPRENEURSHIP AND SUSTAINABILITY ISSUES

ISSN 2345-0282 (online) http://jssidoi.org/jesi/aims-and-scope-of-research/

\title{
MAIN FOREIGN DIRECT INVESTMENT FACTORS AS PRECONDITION OF SUSTAINABLE ENTREPRENEURSHIP: EVIDENCE FROM LITHUANIA, CENTRAL AND EASTERN EUROPE
}

\author{
Violeta Šabasevičienè $\dot{1}^{1}$ Virginija Grybaitė ${ }^{2}$ \\ ${ }^{1,2}$ Vilnius Gediminas Technical University \\ Sauletekio al. 11, LT-10223 Vilnius, Lithuania \\ E-mails: ${ }^{1}$ violeta.sabaseviciene@gmail.com; ${ }^{2}$ virginija.grybaite@vgtu.lt \\ Received 08 January 2014, accepted 28 May 2014
}

\begin{abstract}
Foreign direct investment plays an important role in most economies. Business conditions and sustainable entrepreneurship is being directly affected by country's ability to attract inflows of foreign capital. Hence, a question how to draw them in is one of the most important aims and goals of foreign policy. Some countries are successful in attracting foreign investment, others stay on the sidelines. The inflow of foreign direct investment depends on various factors. This article aims to answer the question which foreign direct investment factors have a positive effect on the flow of these investments into chosen countries in Central and East European countries. The data retrieved and used for consideration embraces period from 2003 to 2013.
\end{abstract}

Keywords: Foreign Direct Investment (FDI), Gross Domestic Product (GDP), sustainable entrepreneurship

Reference to this paper should be made as follows: Šabasevičienė, V.; Grybaitè, V. 2014. Main foreign direct investment factors as precondition of sustainable entrepreneurship: evidence from Lithuania, Central and Eastern Europe, Entrepreneurship and Sustainability Issues 1(4): 230-238.

DOI: http://dx.doi.org/10.9770/jesi.2014.1.4(5)

JEL Classifications: F21, F23

\section{Introduction}

Considering the issue of global economy recovery, especially in regard to the stability of European Unions economy, a lot of attention is given to the international cooperation, free movement of capital, goods and services, integration of societies, encouragement of technological innovations and increasing competitiveness between countries. In other terms, issues of sustainable development (Tvaronavičienè 2014; Korsakienė and Tvaronavičienė 2014; Šimelytė and Antanavičienė 2013; Tvaronavičienè and Lankauskienė 2011; Dudzevičiūtė 2013; Vasiliūnaitė 2014; Antanavičienė 2014; Mačiulis and Tvaronavičienė 2013; Tvaronavičienė et al. 2013) and sustainable entrepreneurship (Korsakienė 2013; Korsakienė and Baranauskienè 2011; Wahl and Prause 2013; Laužikas and Mokšeckienė 2013; Balkienė 2013) are being raised. Foreign direct investment (FDI) is almost unanimously seen as precondition of sustainable development and sustainable entrepreneurship. Scientific research and discussions about positive and negative effect of investment, factors determining the attraction of investment and appealing investment environment, are topical not only in other countries, but also in Lithuania. 
The effect of foreign direct investment on the economic growth, export, magnitude of production, employment, scientific research and technological development, survival of businesses etc. (Unit and Mustafa 2007; Faras and Ghali 2009; Weng et al. 2010 and others.). However theoretical analysis of scientific literature shows that relocation of foreign capital from one country to the other can have controversial effect on the receiving country's economy (Davulis 2009: 343; Žilinske 2010). This type of investment can be affected by country's uneven economical development, profit export, the lack of reinvestment and predominance in strategic branches of economy. However, the majority of researchers imply that foreign direct investment has more positive effect on the economic growth than negative; they underline that the bigger effect of such investments on country's economy depends on the receiving country's level of development. In other words, general technological level, work force qualification, institutional factors, etc. as well as the investors' aims and nature and potential of their activity. Positive attitude towards these types of investments results in a certain type of foreign capital politics: countries try to look attractive for the foreign investors, specific strategies and programs designed to draw in investment are created. Foreign investment is riskier than domestic one, therefore factors, which encourage foreign direct investment, are widely discussed in scientific literature. However it should be noted that the opinion on this issue is not unanimous.

The aim of this article is to determine and evaluate the main factors which influence decisions to invest in the Central and Eastern European countries by the amount of investment they attract. Applied methods of research: analysis, synthesis and summary of scientific works and normative documents; comparative and logical analysis of statistical data; horizontal and vertical analysis; graphical demonstration of data; analysis by correlation; Method of Stiuden criterion. The article is structured as follows: first we present an overview of different theoretical approaches to the mains factors which encourage foreign direct investment into the country, overview of scientific literature is presented. Second we investigate foreign direct investment into Central and Eastern European (CEE) countries. The position of Lithuania in CEE context is established, and countries for the further investigation are chosen. In order to check the strength of connection between the main driving factors and FDI, correlative analysis was applied, and the decision about the significance of correlative coefficient size is made using statistics $t$ (Student criterion method).

\section{FDI driving factors}

Factors encouraging foreign direct investment (FDI) are widely analyzed by many scientists, therefore there is no consensus about the motivation for these investments. Of course, while penetrating markets of the foreign countries investors have many motives and aims and, first and foremost, try to evaluate the image and economic environment of the country (Kahai 2011). Why businesses decide to invest into foreign markets is discussed by few widely spread theories. The most famous one is Dunning (1981) theory of expansion also called $O L I$ theory of conditions. This theory answers the question why it is better to invest abroad and not to increase production in one's own country and to sell it abroad or to sell the license of production for the foreign business.

Other theories such as production cycle theory, monopolist superiority theory, internationality theory, according to Navickas (2008: 150), are mainly oriented only to a certain aspect of foreign investment, certain group of main factors. Meanwhile, the decision to invest abroad is usually affected by the group of factors, which is based on many theories. The pursuit of bigger effectiveness with the help of FDI helps distribute resources more rational, and monitoring of the market - investing in a way that would bring the biggest profit from geographically spread activity. Accroding to Tvaronavičiene et al. (2008) the expansion of the investing country's market can be secured in two cases. First case is when country receiving investments is geographically big and has a big population, second case is when the country is small, but show stabile growth of economy, which promises additional market capabilities for the investors. Rajan (2004) claims that foreign country as a suitable location for investment is usually has two stages of evaluation. In the first stage they evaluate countries by the crucial factors. Later only those countries are analyzed, which match that criteria, such as tax level, subsidies provided by the country and other incentives. Both theoretical arguments and empirical research conclusions form an attitude that various foreign direct investment incentives at the moment are important factors, affecting the choice of location for these investments. Easson and Zolt (2002) admit the growing importance of country's incentive system for the investors especially, when choosing 
between the countries in the same region. Almost every government, in spite of their political affiliation, actively carries out politics towards international business (Ginevičius, Šimelytė 2011). According to Ginevičius et al. (2005: 175) in order to attract solid foreign direct investment it is not enough to regulate the processes, but it is also important for the state to stimulate them by economical means.

In the recent decade institutions are increasingly more often named as one of the most important factors in attracting FDI. Institutions are becoming one of the main advantages of the country receiving investments, because the effectiveness of the market strongly depends on the institutions regulating it, as they define "the rules of the game", which determine the amount of expenses and availability of the information, which accordingly defines how successful the business is (Rupliene et al.2008). If the institutions are effective, they can attract additional FDI, meanwhile if they are not; it can accumulate additional foreign investment expenses. It is especially connected with corruption. In addition, FDI is especially sensitive towards any kind of institutional instability, political changes, diminishing of ownership rights protection, and it can even result in withdrawal of investment.

Caetano and Galego (2009) define connection between FDI and institutions. Firstly, qualified country's institutions decrease the expenses for investment agreements, therefore profitability increases. Secondly, because of undergone irreversible big expenses (especially in the case of Greenfield investment) FDI is sensitive towards the stability of the country and its changes in security, which depend on the effectiveness of the legal system and protection of the ownership rights. Hyun (2006), who as well studied the effect of quality of institutional activities on attraction of foreign direct investment, also claims that the quality of institutions is one of the most important factors attracting foreign investment. This author also underlines that the growth of institutional quality has effect on the economic growth only in the long-term. Dumludag (2009) confirms that institutions can affect decisions related to FDI and their amount in the separate economies. According to Rupliene (2009), authors evaluating the influence of institutional factors on the FDI, among which tax system is believed to be the most important one, often support their ideas by the main factors theory - Dunning OLI paradigm. Taxes can affect all three conditions mentioned in this theory. For example, if tax concessions are applied for foreign investors, they gain an advantage in comparison with local businesses. Taxes can also be a factor resulting in making a certain place more attractive for the investment.

However, the flow of FDI is affected not only by the policy of the state and the quality of institutions, but also is important and geographical location (Ginevičius et al. 2005: 161), various infrastructures and their institutionalization, which also change in time and space (Held et al 2002: 216). However, according to Margalioth (2003) because of globalization the influence of main country's factors towards investment decisions has decreased hugely. Progress and development in many areas enables international companies to move their manufacturing process into other countries. Kostiunina and Livencov (2001: 70) underlines the importance of the growing importance of these factors:

- The openness of national economy. Open economy attracts more investments. According to Ruplienè et al. (2008), this coefficient shows how effectively the country participates in the world's trade and is linked with smaller limitations of the foreign trade, and it affects bigger migration level of the capital.

- The level of infrastructural development. The quality of infrastructure is important for the development of world's production and trade; therefore it is necessary to improve the system of transportation, logistics and telecommunications.

Gholami et al. (2006) also distinguishes the most commonly analyzed factors in the scientific literature natural resources, the size of the market, political stability, the conditions for business activity, small wages, favorable currency rate, trade barriers, orientation towards export, the openness of the developing country, democratization, etc. and these factors are indicated as traditional factors affecting foreign direct investment. However, as the authors underlined these factors due to changes in global economy are not as important. According Gholami et al. (2006); Soper et al. (2012) in the future informational technologies and telecommunication will be one of the main factors attracting foreign direct investments. Informational technologies and telecommunication constructs more favorable conditions for the development of activity in the international markets, installing new models of business, provides a possibility translate data about goods, orders and cargos in an actual time. 
Bevan and Estrin (2000) analyze the flow of FDI form eighteen market economies to eleven future European Union countries in the period from 1994 to 1998. After the research was carried out, it was find out that FDI into these markets has been increasing during the analyzed period, and they are affected by cheap labor, big market and geographical closeness. The authors come to conclusion that joining unions is also a valid factor affecting FDI, because it is related with the decrease economical indeterminability and the increase of the country's reliability. Nonnemberg and Mendonca (2004) analyze factors influencing FDI in 38 developing countries in the period from 1975 to 2000 . Authors determined the factors affecting FDI inflows: the level of education, economic openness, inflation, economic risks and tempo of economic development. BenassyQuere et al. (2007) defines the importance of institutions and its impact on FDI, emphasizing the bureaucracy and corruption. Ruplienè et al. (2008) evaluated Lithuanian annual FDI dependence on three macroeconomic indicators - average salary, average income per capita and economical openness. Authors have found out that economic openness compare with other two factors have the greater impact on flow of FDI. Cevis and Camurdan (2009) explored which of factors: salary, inflation, interest rate or the growth of gross domestic product have the greatest impact on the flow of FDI in 17 countries. Cevis and Camurdan (2009) found out that the flow of FDI is directly affected by the changes of interest rates and the growth of GDP, and the greatest impact has the income of the previous FDI period. Nur Ozkan-Gunay (2011) defined different motives for investing into new and old EU members in the period from 1998 to 2008. While attracting FDI into old EU members, such factors as price of energy resources, technologies saving resources, innovations and investment into human resources are important. Macroeconomic stability is not a valid factor for attracting FDI into old EU countries. FDI into the new EU countries is encouraged by economic stability, the size of domestic market, tax factors and small price of work force. Dumludag (2009) showed that political stability, superiority of the law, corruption, democracy, bureaucracy and the protection of the ownership rights have a major effect on direct foreign investment.

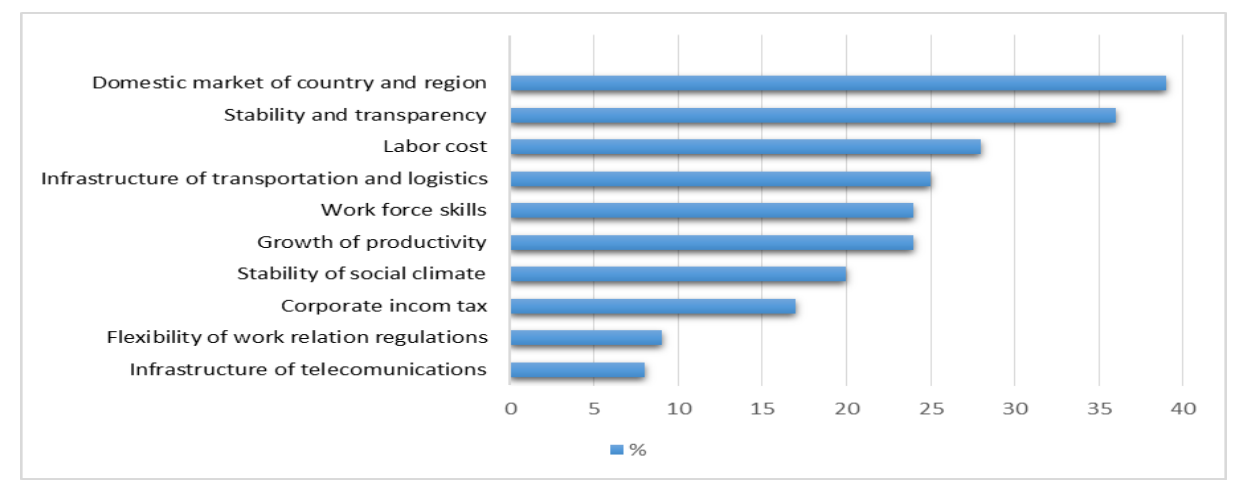

Fig. 1. Factors, which influence investors' priorities in choosing the direction of investment

Source: Feasibility study for... 2012

As one can see scientists tend to choose various factors for empirical researches, they use different statistical data, periods of time, methods of research, carry out their researches in different countries and regions, therefore they get different results. In 2011 during the survey, carried out by "Ernst \& Young", about the attractiveness of Europe for investment, investors named the quality of communication and infrastructure of telecommunication as the main factor affecting the choice of direction, region and country of investment. The data from 2012 questioners show that the priorities of the investors change: they named the attractiveness of the market of the country or region and the stability and transparency of political, legal and regulative environment as the most important ones. The expenditure for the workforce, infrastructure, and the amplification of the productivity still remain to be important factors, however, investors are looking for the regions, which have bigger consumer market and the trust of consumers regaining after economic recession. The change in economic conditions also has a major impact on the investors' goal to decrease the risks of business - invest in the regions, which have stabile legal and regulative environment (Feasibility study for ... 2012). The Figure 1 demonstrates the most important factors, which impact investors' decisions in choosing a region or a country of investment, named in the "Ernst \& Young" European attractiveness 
questionnaire of 2012 (840 respondents). Named investors' priorities for choosing direction of investment helps to explain why certain countries attract more attention from investors than others.

\section{Foreign direct investment in CEE countries}

In spite of euro zone crisis and instability of continental economy investors value Europe is an attractive location for the investment. In 2011 according to the data of "Ernst \& Young" survey West Europe was able to keep stabile position among the most attractive regions for investments: 33 percent of questionnaire respondents, when making a decision about the development of their managed organization, would choose West Europe, 21 percent would invest in Central and Eastern Europe (CEE) (Feasibility study for... 2012). Central and Easter European countries before the collapse of Soviet Union were practically closed for foreign investment. However, during the last two decades this region changed dramatically. Soviet type central plan economy was changed by free market model. Just a few years ago CEE was considered a region of small expenditures, which caters for citizens from West Europe with big consumerist needs. However, economic disturbances in The West had a negative effect on CEE. Bad loans, dependence on export to the West, weak bank system also had a negative effect the attractiveness of CEE. In addition to these reasons, investors have noticed that work force expenses in CEE has grown as well, therefore production in the region does not seem to be as attractive. Due to growing attractiveness of quickly growing BRIC countries and other developing markets of investment, region is facing strong competition (Feasibility study for... 2012). In order to distinguish countries, which are the first and the last by their ability to attract FDI and to evaluate the position of Lithuania in CEE context thereinafter comparison of direct investment per capita in CEE countries is carried out. As countries differ in their size and level of development, in order to compare them most adequate is foreign direct investment per capita. Figure 2 shows average (arithmetical average) FDI per capita in 2003-2012 and the change (the speed of growth) in 2012 in comparison with 2003 in CEE countries.

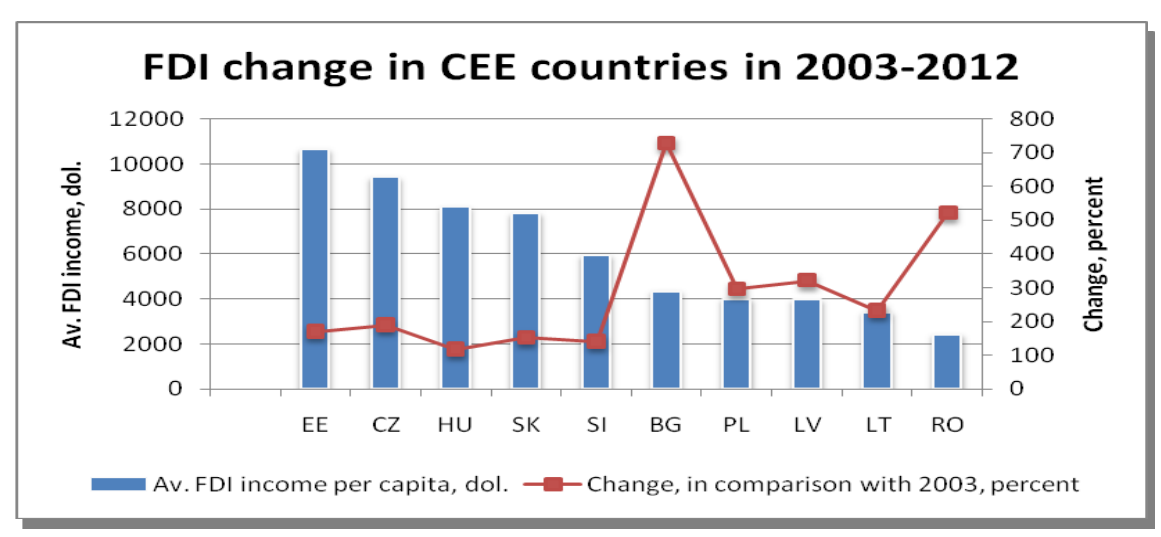

Fig. 2. Av. FDI per capita in 2003-2012 and the change in 2012 in comparison with 2003 in CEE countries

Source: Compiled by the authors. Based on data from UNCTAD

As one can see from the Figure 2, average FDI revenue per capita is the biggest in Estonia 10 666,87 dollars. The Czech Republic and Hungary on average attracted 11,65 and 24,05 percent less FDI then in Estonia. Meanwhile, these investments are 67,83 and 77,28 percent smaller in Lithuania and Romania, in comparison with Estonia. However, FDI has increased in Romania since 2012, in comparison with $2003-523$ percent. Statistical data show that foreign capital flow into Lithuania is significantly smaller than to other CEE countries. We will try to learn about the advantages that Estonia and the Czech Republic have in comparison with Lithuania and Romania during further investigation.

\section{Significance of main FDI driving factors}

After the analysis of scientific works, the main factors encouraging and limiting FDI attraction to the country were discovered. This part evaluates how much FDI influx into the Czech Republic, Estonia, Lithuania and Romania is affected by such main quantitavely evaluative factors as the Corruption Perceptions Index, the 
Index of Economic Freedom, the Size of the Market, Average Monthly Wage, the Tax Burden, Expenses for the Research and Development and the Level of Economic Openness. In order to check the strength of connection between the before mentioned factors and FDI correlative analysis was used, and the decision about the significance of correlative coefficient size is made using statistics $t$ (Student criterion method).

Lithuania and other three CEE countries (Estonia, the Czech Republic and Romania) as an object of research provides the opportunity to evaluate the significance of the main FDI factors for these investments into the first and the last countries by their FDI attraction. An assumption that such directly evaluable quantitative factors as the Corruption Perceptions Index, the Index of Economic Freedom, the Size of the Market, Average Monthly Wage, the Tax Burden, Expenses for the Research and Development and the Level of Economic Openness impact the flow of investment into the country.

After the research of foreign direct investment main factors, while using correlation analysis (Table 1), in the discussed period the strongest connection was established between FDI and GDP and between FDI and expenses for Research and Development in all countries.

Table 1. FDI subordination to the index of the main factors

\begin{tabular}{|l|l|l|l|l|l|l|l|l|l|}
\hline \multirow{2}{*}{ Factors } & \multicolumn{2}{|c|}{ Czech Republic } & \multicolumn{2}{|c|}{ Estonia } & \multicolumn{2}{c|}{ Lithuania } & \multicolumn{2}{c|}{ Romania } & t \\
\cline { 2 - 10 } & $\mathbf{R}$ & $\mathbf{T}$ & $\mathbf{R}$ & $\mathbf{t}$ & $\mathbf{r}$ & $\mathbf{t}$ & $\mathbf{r}$ & $\mathbf{t}$ \\
\hline Corruption Perceptions Index & 0,6306 & 2,2982 & 0,7194 & 2,9298 & 0,6356 & 2,3288 & 0,9188 & 6,5839 \\
\hline Index of Economic Freedom & 0,7870 & 3,6077 & $-0,5631$ & 1,9273 & 0,1366 & 0,3901 & 0,9889 & 18,8124 \\
\hline Market Size & 0,9359 & 7,5144 & $-0,9818$ & 14,6123 & $-0,9319$ & 7,2666 & $-0,9466$ & 8,3018 \\
\hline GDP & 0,9638 & 10,2253 & 0,9437 & 8,0705 & 0,9461 & 8,2658 & 0,9638 & 10,2298 \\
\hline Av. Montly Wage & 0,9738 & 12,1050 & 0,9550 & 9,1119 & 0,9054 & 6,0329 & 0,9853 & 16,3137 \\
\hline Tax Burden & & & & & & & \\
\hline R\&D expenses & $-0,6734$ & 2,5762 & 0,5999 & 2,1208 & $-0,1433$ & 0,4096 & 0,1115 & 0,3173 \\
\hline The Level of Economic Openness & 0,3644 & 1,1069 & 0,4823 & 1,5571 & 0,7806 & 3,5320 & $-0,2100$ & 0,6076 \\
\hline
\end{tabular}

Source: compiled by the authors

The importance of other factors differs from country to country. The Corruption Perceptions Index is significant to FDI in Estonia, Lithuania and Romania, the Index of Economic Freedom - The Czech Republic and Romania, Market Size and Tax Burden - The Czech Republic, the Level of Economic Openness Lithuania. In conclusion, one can claim that in the analyzed period some correlations based on scientific works and established in other countries, were not confirmed or only partly confirmed in the analyzed countries.

After analysis was carried out, it was noticed that The Czech Republic and Estonia, where in the analyzed period the biggest Average Monthly Wage and Tax Burden and in Estonia even the smallest market in the sense of population were established, are the leading countries in CEE by FDI attraction. Lithuania and Romania, on the other hand, in spite of more favorable indexes in these areas are behind. Therefore, the increase of taxes and wages may not have a noticeable negative effect on FDI attraction. As work force expenses are growing, work force skills and the increase of productivity are becoming more important factors, while tax size is not so important when tax concessions are offered. Meanwhile, in the leading countries by the FDI attraction other factors - the Corruption Perceptions Index and the Index of Economic Freedom (which define the quality of institutions), GDP (which defines the growth of economy and 
purchasing power), expenses for Research and Development, the Level of Economic Openness - significance is the biggest, and in those behind - smaller. Consequently, Lithuania and Romania in order to increase the flow of FDI should improve the quality of institutional environment, because due to corruption, political instability or excessive amount of regulations foreign investors avoid these countries. More active participation of the countries in world trade would result in bigger foreign capital inflow to the countries. However, because of determined strong connection between FDI and expenses for Research and Development, the biggest amount of attention should be designated for this area. Also it should be kept in mind that analyzed factors only form a small part of factors, which can affect the amount of FDI in the country. Other factors which are not analyzed in this article can also have effect on FDI. Moreover, it is important to mention that it is most common that business decision to invest abroad is a result not just of one factor, but of their complex. It is also difficult to forecast which factors can influence the dynamics of FDI and direction in modern global economy. Because of the global changes traditional factors are becoming less important. Also the factors which impact the flow of FDI into the developing or transitive economies are not valid factors in advanced countries.

\section{Conclusions}

The review of scientific literature reveals that various researchers define different factors, which determine investment decisions, and they do not interpret in a same manner their importance in FDI attraction. According to various authors the flow of FDI can be influenced by: stabile political and economic situation, strong national currency, the openness of national economy, the balance of price and quality of work force, the size of tax and concessions, appropriate infrastructure and communication accessibility, favorable maintenance of legal and institutional environment, the possibility to access resources, the size of the market and the possibility for its growth, etc. Scientists obtained different results, they choose different factors for their empirical researches, use different statistical data, periods of time, methods of research, carry out their researches in different countries and regions.

Different CEE countries attracted different amount of foreign capital in period from 2003 to 2012. Estonia, the Czech Republic, Hungary are successful in attracting foreign capital. However Lithuania and Romania stay aloof. After the chosen FDI factors' research was carried out - the Corruption Perceptions Index, the Index of Economic Freedom, the Size of the Market, Average Monthly Wage, the Tax Burden, Expenses for the Research and Development and the Level of Economic Openness - in Estonia, the Czech Republic, Lithuania, Romania, in the analyzed period (2003-2012), the strongest connection was established between FDI and GDP and between FDI and Expenses for Research and Development in all countries. The significance of different factors varies depending on the country and in the analyzed countries they were not confirmed or confirmed only partly. Therefore, it means that reliable conclusions can not be made, in other words, other FDI factors, not analyzed in this article exist.

\section{References}

Antanavičienė, J. 2014. Foreign direct investment: driving factors and outcomes for secure and sustainable development, Journal of Security and Sustainability Issues 3(3): 55-67. DOI: http://dx.doi.org/10.9770/jssi.2014.3.3(5)

Balkienè, K. 2013. Sustainable innovativeness: issues and public policy, Journal of Security and Sustainability Issues 3(2): 53-76. DOI: http://dx.doi.org/10.9770/jssi.2013.3.2(5)

Benassy-Quere, A.; Coupet, M.; Mayer, T. 2007. Institutional Determinants of Foreign Direct Investment, The World Economy 30: 764-782.

Bevan, A.; Estrin, S. 2000. The Determinants of Foreign Direct Investment in Transition Economies, CEPR Discussion paper 2638.

Caetano, J.; Galego, A. 2009. FDI in European Union and Mena Countries: Institutional and Economic Determinants, CEFAGE-UE Working Paper 9.

Cevis, I.; Camurdan, B. 2009. The Economical Determinants of Foreign Direct Investment in Developing Countries and Transition Economies, E-Journal of new world sciences academy 4(3): 210-223.

Davulis, G. 2009. Ekonomikos teorija [Economics theory]. Vilnius: Mykolas Romeris university. 
Dudzevičiūtè, G. 2013. Lithuanian manufacturing trends in the context of developed and developing countries, Entrepreneurship and Sustainability Issues 1(1): 55-66. DOI: http://dx.doi.org/10.9770/jesi.2013.1.1(6)

Dumludag, D. 2009. An Analysis of the Determinants of Foreign Direct Investment in Turkey: the Role of the Institutional Context, Journal of Business Economics and Management 10(1): 15-30.

Dunning, J. 1981. Explaining the international direct investment position of countries: Towards a dynamic or developmental approach, Review of World Economics 117(1): 30-64.

Easson, A.; Zolt, E. M. 2002. Tax Incentives, World Bank Institute. Available on the Internet: <http://siteresources.worldbank.org/INTTPA/Resources/EassonZoltPaper.pdf>

Faras, R. Y.; Ghali, K. H. 2009. Foreign Direct Investment and Economic Growth: the Case of the GCC Countries, International Research Journal of Finance and Economics 29: 134-145.

Gholami, R.; Lee, S. Y. T.; Heshmati, A. 2006. The Causal Relationship Between Information and Comunication Technology and Direct Foreign Investment, Journal of International Economics 38: 105-118.

Ginevičius, R.; Rakauskienė, O. G.; Patalavičius, R.; Tvaronavičienė, M.; Kalašinskaitè, K.; Lisauskaitė, V. 2005. Eksporto ir investicijų plètra Lietuvoje [Export and Investment Development in Lithuania]. Vilnius: Technika.

Ginevičius, R.; Šimelytė, A. 2011. Valstybès politikos taikymo tiesioginėms užsienio investicijoms pritraukti teorinės įžvalgos, Verslas: teorija ir praktika [Business: theory and practice] 12(3): 225-235.

Held, D., McGrew, A., Goldblatt, D., Perraton, J. 2002. Globaliniai pokyčiai: politika, ekonomika ir kultūra [Global changes: politics, economy and culture]. Vilnius: Margi raštai.

Hyun, H. J. 2006. Quality of Institutions and Foreign Directinvestment in Developing Countries: Causality Tests for Crosscountry Panels, Journal of Business Economics and Management 7(3): 103-109.

Kahai, S. K. 2011. Traditional And Non-Traditional Determinants of Foreign Direct Investment in Developing Countries, Journal of Applied Business Research 20 (1): 43-50.

Korsakiene, R. 2013. Internationalization of construction firms: what strategy do they follow? Entrepreneurship and Sustainability Issues 1(2): 99-107. DOI: http://dx.doi.org/10.9770/jesi.2013.1.2(4)

Korsakienè, R.; Baranauskienè, A. 2011. Factors impacting sustainable internationalization: a case of multinational company, Journal of Security and Sustainability Issues 1(1): 52-60. DOI: http://dx.doi.org/10.9770/jssi.2011.1.1(5)

Korsakienè, R.; Tvaronavičienė, M. 2014. Processes of economic development: case of Lithuanian real estate sector, Entrepreneurship and Sustainability Issues 1(3): 162-172. DOI: http://dx.doi.org/10.9770/jesi.2014.1.3(5)

Kostiunina, G.; Livencov, N. 2001. International practice of foreign investment regulation. Moscow. (in Russian)

Laužikas, M.; Mokšeckienè. 2013. The role of creativity in sustainable business, Entrepreneurship and Sustainability Issues 1(1): 10-22. DOI: http://dx.doi.org/10.9770/jesi.2013.1(2)

Lietuvos verslo tarptautinès plètros galimybių studija [Feasibility study for the International Development of Lithuanian Business]. 2012. Available on the Internet: < http://www.investorsforum.lt/files/BIF_studija_pilna_final_2013_01_22.pdf>.

Mačiulis, A.; Tvaronavičienè, M. 2013. Secure and sustainable development: Lithuania's new role in taking the Presidency of the EU, Journal of Security and Sustainability Issues 3(2): 5-13. DOI: http://dx.doi.org/10.9770/jssi.2013.3.2(1)

Margalioth, Y. Y. 2003. Tax Competition, Foreign Direct Investments and Growth: Using the Tax System to Promote Developing Countries, Virginia Tax Review 23: 157-200.

Navickas, V. 2008. Europos Sajungos rinkų ypatumai [The characteristics of the markets of the European Union]. Kaunas: Technologija.

Nonnemberg, M. B.; Mendonca, M.J.C. 2004. The Determinants of Foreign Direct Investment in Developing Countries, Proceedings of 3ed Brazilian Economies Meeting.

Nur Ozkan-Gunay, E. 2011. Determinants of FDI Inflows and Policy Implications: A Comparative Study for the Enlarged EU and Candidate Countries, Emerging Markets Finance \& Trade 47( 4): 71-85.

Rajan, R. S. 2004. Measures to Attract FDI: Investment Promotion, Incentives and Policy Intervention, Economic and political Weekly 39(1): 12-15. 
Ruplienè, D. 2009. Verslo mokesčių dydžio kaip institucinio veiksnio įtaka tiesioginėms užsienio investicijoms [The Impact of Tax Rate as Institutional Determinant in Foreign Direct Investment], Ekonomika ir vadyba: aktualijos ir perspektyvos [Economics and Management: Current Issues and Perspectives] 1 (14): 248-255.

Ruplienè, D.; Montvilaitè, K.; Grigaliūnienè, Ž. 2008. Tiesiogines užsienio investicijas lemiantys veiksniai [Determinants of Foreign Direct Investment], Ekonomika ir vadyba: aktualijos ir perspektyvos [Economics and Management: Current Issues and Perspectives] 3(12): 271-280.

Soper, D. S.; Demirkan, H.; Goul, M.; St. Louis, R. 2012. An Empirical Examination of the Impact of ICT Investments on Future Levels of Institutionalized Democracy and Foreign Direct Investment in Emerging Societies, Journal of the Association for Information Systems 13(3): 116-149.

Šimelytè, A.; Antanavičienè, J. 2013. Economic development and its influence on state capital structure, Entrepreneurship and Sustainability Issues 1(1): 1-9. DOI: http://dx.doi.org/10.9770/jesi.2013.1(1)

Tvaronavičienè, M. 2014. If industrial sector development is sustainable: Lithuania compared to the EU, Entrepreneurship and Sustainability Issues 1(3): 134-142. DOI: http://dx.doi.org/10.9770/jesi.2014.1.3(2)

Tvaronavičienė, M.; Grybaite, V.; Korsakienė R. 2008. Foreign Capital Destinations: Baltic States Versus India, Journal of Business Economics and Management 9(3): 227-234.

Tvaronavičienė, M.; Grybaite, V.; Tunčikienė, Ž. 2013. Globalization drivers in developed and less developed countries: if consistent patterns can be traced, Journal of Security and Sustainability Issues 2(4): 5-11. DOI: http://dx.doi.org/10.9770/jssi.2013.2.4(1)

Tvaronavičienè, M.; Lankauskienè, T. 2011. Plausible foreign direct investment'impact on sustainable development Indicators of differently developed countries, Journal of Security and Sustainability Issues 1(1): $25-36 . \quad$ DOI: http://dx.doi.org/10.9770/jssi.2011.1.1(3)

UNCTAD. United Nations Conference on Trade and Development. Available from: <http://www.unctad.org>

Unit, G.; Mustafa, Y. 2007. The Effect of FDI on Economic Growth: A Panel Data Evidence for Developing Countries, Journal of Academic Studies 34: 1-13.

Vasiliūnaite, R. 2014. Sustainable development: methodological approaches toward issues, Journal of Security and Sustainability Issues 3(3): 69-75. DOI: http://dx.doi.org/10.9770/jssi.2014.3.3(6)

Wahl, M.; Prause, G. 2013. Toward understanding resources, competencies, and capabilities: business model generation approach, Entrepreneurship and Sustainability Issues 1(2): 67-80. DOI: http://dx.doi.org/10.9770/jesi.2013.1.2(1)

Weng, Y.; Yang, Ch. H.; Tu, F.Ch. 2010. Outward Foreign Direct Investment and Product Quality of Domestic Productions: an Empirical Investigation, Journal of Business Economics and Management 11(3): 396-414.

Žilinskè, A. 2010. Incoming Foreign Investment: holly water or menu of potential troubles? Inžinerine Ekonomika [Engineering Economics] 21(5): 518-524.

Violeta ŠABASEVIČIENĖ- master of business management obtained at Vilnius Gediminas Technical University. Currently works in a business company. Research interests: foreign direct investment, economic development, entrepreneurship.

Virginija GRYBAITÉ is a lecturer at Vilnius Gediminas Technical University. Research interests: sustainable development, economic growth, investments, institutional environment. She is an author and co-author of 20 scientific papers, published in scientific journals, indexed and abstracted in numerous international databases. Grybaite is a member of editorial boards of peerreviewed scientific journals. 